\title{
Redistributing under fiscal constraint: partisanship, debt, inequality and labour market regulation
}

\author{
Lasse Aaskoven ${ }^{*}$ \\ Department of Political Science, University of Copenhagen, København, Denmark \\ ${ }^{*}$ Corresponding author. Email: lasseaaskoven@hotmail.com
}

(Received 9 February 2017; revised 17 May 2018; accepted 10 June 2018;

first published online 16 July 2018)

\begin{abstract}
Labour market regulation varies significantly, both within and between developed democracies. While there has been extensive research and debate in economics on the consequences of labour market regulation, the political causes for levels and changes in labour market regulation have received less scholarly attention. This article investigates a political economy explanation for differences in labour market regulation building on a theoretical argument that labour regulation can be used as a nonfiscal redistribution tool. Consequently, partisanship, the demand for redistribution and government budget constraint jointly determine whether labour market regulation will increase or decrease. Consistent with this argument, panel analyses from 33 Organisation for Economic Co-Operation and Development countries reveal that labour market regulation increases under left-wing governments that face increased market inequality and high government debt.
\end{abstract}

Keywords government debt; government ideology; inequality; labour market regulation; redistribution

\section{Introduction}

In 2015, the United States (US) Democratic Party decided to make a campaign for a significant increase in the federal minimum wage part of their national party platform. Previously, president Barack Obama had issued an executive order in 2014 to raise the minimum wage for federal government contractors and repeatedly called for a general minimum wage increase. By the end of 2015, raising the minimum wage had become one of the top issues for the American centre-left. Ten years earlier, the German social-democratic government under Chancellor Gerhard Schröder had implemented labour market reforms known as the Hartz reforms, some of which enabled workers to hold jobs at wages below the standards of previous collective agreements, which are normally a pillar of the German coordinated labour market (Kemmerling and Bruttel 2006, 98). While one left-of-centre government party decided to make increases in minimum wage stringency a top 
priority, the other engaged in an effective partial deregulation of the national wage floor. The positions of left-wing parties also change within countries over time, however, as became evident in Germany where, several years after having implemented the Hartz reforms, the German Social Democratic Party also made the introduction of a national minimum wage its top political priority, which became implemented when it joined a government coalition after the 2013 election (Meyer 2016, 30-31). This article theoretically and empirically investigates the reasons why we see such divergent patterns in the role of left-wing parties regarding labour market regulation, even within countries.

Labour market regulation, defined here as the formal, nonfiscal regulation of national labour markets, including hiring and firing regulations, the nature and stringency of minimum wage regulation, the formal support for collective bargaining systems and related policies, is both a timely and hotly debated topic both in both academic and policy circles. An oft-made argument is that high levels of labour market regulation have adverse effects on employment (Botero et al. 2004; Feldmann 2009) and economic growth (Djankov et al. 2006) ${ }^{1}$ and could increase informal sector size (Schneider 2010). Differences in labour regulation have been singled out as a key explanation for the very different economic and employment experiences of the US and continental Europe in recent decades, where there has been extensive scholarly and policy debate in this area (Siebert 1997; Nickell and Layard 1999), a discussion and research agenda which is continuing (Dew-Becker and Gordon 2008).

Several Organisation for Economic Co-Operation and Development (OECD) countries have enacted labour market reforms in recent decades. After the financial crisis and subsequent European debt crises, labour market reforms have been singled out as one of the pillars of structural reforms, especially in Southern Europe. However, significant differences still exist between advanced economies with regards to labour market regulation and reform tendencies. Some countries have experienced a shift towards more deregulated labour markets, others display general inertia regarding labour market regulation, while others yet experience tandems in labour market deregulation, with deregulation followed by increased labour market regulation.

This article concerns the effects of partisanship on labour market regulation. It argues that some of the variation and patterns of change in labour regulation among and between developed democracies can be explained by the different stances of incumbent left-wing governments. In line with recent scholarship on partisanship and differences in public policies (Häusermann et al. 2013), the argument is that the policy stance of left-wing governments is contingent on moderating factors. In this case, the actions of left-wing governments regarding labour market regulation are a function of government budgetary constraints, in the form of high government debt, and market income distribution.

The line of argument is that labour market regulation can serve redistributive functions. Governments can hold partisan preferences, and a left-wing government is interested in serving the interests of below-average-income citizens. Increased market inequality reduces the relative market income of below-average citizens while increasing the demands for redistribution from these citizens to whom leftwing government parties should be responsive. However, if the government is

\footnotetext{
${ }^{1}$ Although measures of labour market regulation are pooled with other measures of regulation.
} 
under high levels of perceived budgetary constraint as in the case of high government debt, increased fiscal redistribution is both financially and politically less viable for an incumbent left-wing government. Under such circumstances, redistribution through increased labour market regulation becomes an attractive option. Consequently, when an incumbent left-wing government is faced with an increase in market inequality but also faces high levels of government debt, the left-wing government will increase labour regulation.

The empirical part of this article investigates this theoretical argument using panel analyses of general labour market regulation in 33 OECD countries. The findings strongly support the theoretical argument. Increased market inequality causes left-wing governments to increase labour market regulation, but only when government debt levels are high.

The rest of the article is structured as follows. The next section establishes the theoretical argument for the joint effect of government partisanship, inequality and government debt on labour market regulation. The data and estimation method used to test the theoretical prediction are then described. The following section describes the results from the test of the theoretical prediction. The final section discusses the results.

\section{Theory}

The basic theoretical argument for why we should experience different approaches to labour market regulation under left-wing governments contingent on inequality and government debt levels is that higher market inequality, which widens the gap between the citizens with the average income and those with below average income, increases the relative value of government spending for below-averageincome citizens in line with classical models of redistributive politics (Meltzer and Richard 1981). In accordance with a partisan preferences' approach to politics, leftwing governments should be relatively more responsive to the preferences of the below-average-income citizen than non-left-wing governments. Consequently, it will adjust its policy profile in the area of public spending to changes in inequality, while a non-left-wing government will not. The notion that left-wing and non-leftwing parties react differently to increased inequality is in line with previous empirical findings (Pontusson and Rueda 2010; Tavits and Potter 2015) and general assumptions in the partisan politics literature (Hibbs 1977; Iversen and Soskice 2006).

A left-wing government facing higher market inequality should then attempt to increase fiscal transfers to the below-average-income citizens. High government debt levels, however, constrain the ability of the government to redistribute more fiscal transfers to below-average-income citizens due to the need to meet interest payment obligations and the need to appear fiscally responsible, which it is assumed is also a concern of any incumbent government, including left-wing governments. ${ }^{2}$ This need to appear fiscally responsible also inhibits the use of increased tax revenue to finance increased public transfers, as increased tax revenue is more likely to go towards bringing down government debt in line with findings suggesting that left-wing governments do indeed use increased tax revenue to balance the public budget during times of fiscal consolidation (Tavares 2004).

\footnotetext{
${ }^{2}$ See Hübscher (2016) for a recent piece supporting this view.
} 
Instead, labour market regulation can be used as a distributive tool instead of explicit transfer payments. Labour regulation can reduce the effect of inequality on below-average-income citizen market income, since labour regulation can secure a higher income share from average productivity for the below average income citizens through employment protection, minimum wage laws, capping how many hours can be legally worked a week and other types of labour regulation. Note that labour regulation will not necessarily benefit the very poor in many cases, including those permanently and temporarily outside the labour market. However, the key assumption here is that a left-wing government is attentive towards the welfare of the below-average-income citizens, which is not necessarily the very poor but in many cases citizens with about the median income. Consequently, the left-wing government's choice between representing the interests of labour market outsiders and labour market insiders (Lindvall and Rueda 2014) is not an issue for this theoretical argument.

Increased labour market regulation has the adverse effect of reducing average income, as labour regulation lowers average productivity potential in line with some empirical findings (Besley and Burgess 2004, 93-94), which is why it will be less preferred as a tool to redistribute to the below-average-income citizens than pure fiscal transfers. This issue becomes less of a concern for a left-wing government under high levels of market inequality, however, as greater inequality will mean that productivity gains are disproportionally captured by the citizens with the highest incomes. Under high levels of inequality, a left-wing government should then be more willing to sacrifice average economic efficiency to achieve higher welfare for the below-average-income citizens, which will not be the case if income inequality is low and the productivity loss by higher regulation is therefore also felt by the below-average-income citizens.

Summing up, the above line of argument implies that when a left-wing government faces high debt levels and increased levels of market inequality, it will increase - or at least not decrease - labour market regulation due to redistributive concerns for the below-average-income citizen.

This article is not the first to theorise and test the political determinants of labour market regulation. Several pieces of research in political science and political economy have attempted to assess the causes of the differences in the labour market regulation of advanced economics. ${ }^{3}$ Recent scholarship includes Becher (2010), Potrafke (2010) and Avdagic (2013). However, much of the literature on the determinants of labour market policies is concerned with welfare state aspects of the labour market (e.g. unemployment benefits) rather than pure labour market regulation. Another strain of this literature is concerned with how and whether labour market reforms differently affect labour market insiders who hold steady, often well-protected jobs versus labour market outsiders who are more loosely connected to the formal labour market, and why countries differ in their adoption of reforms related to this area (Davidson and Emmenegger 2013). Since both labour market insiders and outsiders are potentially important left-wing party constituencies, the role of left-wing parties has been an important part of this research agenda. ${ }^{4}$ However, none of the studies above takes the issue of

${ }^{3}$ For a brief review, see Becher $(2010,34)$.

${ }^{4}$ See Lindvall and Rueda (2014) for such a study. 
government fiscal constraint into closer consideration, when assessing whether and how left-wing parties influence labour market regulation.

The article's theoretical argument also bears some resemblance to part of the political economy literature, which also investigates the tradeoff between labour market regulation and explicit public transfers as tools of social protection (Di Giacchino and Sabani 2009; Boeri et al. 2012; Di Giacchino et al. 2014). However, these authors do not provide a more systematic test of the implications of their theoretical argument at the macro-level, whereas this article specifically argues and tests under which conditions policymakers prefer labour market regulation to fiscal transfers. Another related and widely cited theoretical paper on why policymakers sometimes choose to distribute via distortionary policies is Acemoglu and Robinson (2001), who model the choice of redistributive tools as a question of special interest politics rather than partisanship. ${ }^{5}$ The next section describes the data used to test the argument that a left-wing government faced with high debt levels and an increased levels of market inequality will increase labour market regulation.

\section{Data and estimation}

This section contains description of the data and estimation method used to test. The data set consists of an unbalanced panel of 33 OECD countries observed in the years 1985, 1990, 1995 and 2000-2012, where data on labour market regulation is available. Countries that are not OECD members at the start of the panel enter the data set when they become OECD members. The next subsection describes the data and variables in greater detail.

\section{Measuring labour market regulation}

As labour market regulation is the dependent variable of interest, how to quantitatively measure the extent of labour market regulation/deregulation becomes a crucial question. Various international organisations, including the OECD, publish quantitative assessments of the level of labour market regulation, but the OECD's regularly updated data focusses primarily on employment protection levels. However, labour market regulation is arguably a broader concept than merely employment protection. In a study of labour market deregulation and globalisation in OECD countries, Potrafke (2010) uses an OECD data set for labour market regulation covering the years 1982-2003. However, this OECD data for labour market regulation also includes factors such as unemployment benefits' replacements rates and benefits duration, which are related more to fiscal redistribution than to pure regulation. As this article argues that fiscal redistribution and labour market regulation are related but separate factors, the measure of labour market regulation must exclude public transfers and other types of more direct fiscal redistribution.

To capture the broadest potential aspects of labour market regulation while maintaining the focus on nonfiscal sources of labour market regulation in line with the theoretical model, I use an index of labour market regulation that is a

\footnotetext{
${ }^{5}$ In their model, the key purpose of the policy intervention is to keep the size of a given political pressure group stable through subsidisation/regulation in order for the group to keep its political influence.
} 
component in the Economic Freedom Index ${ }^{6}$ published for the years 1985, 1990, 1995 and 2000 and onwards by the Fraser Institute, a Canadian think tank. The index measuring labour market regulation ranges in values from 0 to 10 , lower values denoting higher levels of labour market regulation. I rescale the index in order to make higher values denote higher levels of labour market regulation. The labour market regulation score is based on country scores on six indicators relating to labour market regulation:

- Hiring regulation and the existence and stringency of a minimum wage.

- Hiring and firing regulations.

- Centralised collective bargaining.

- Hours regulation.

- Mandated cost of worker's dismissal.

- The existence and length of conscription.

Data for these indicators come from a variety of sources including the World Bank, World Economic Forum and various other sources (Gwartney et al. 2015, 212-214). The labour market regulation index from the Economic Freedom Index has been used in other cross-national research on the effect of labour market regulation (Feldmann 2009; Freeman 2009, 31).

\section{Explanatory variables}

The key explanatory variable is an interaction between three variables: left-wing control of government, market inequality and government debt. In line with the theoretical prediction, the interaction enables me to observe a potential effect of left-wing partisanship on labour market regulation contingent on inequality and government debt level. Left-wing government is measured by a dummy taking the value 1 if the leader of the government is from a left-wing party based on the Database of Political Institutions (Beck et al. 2001). Market inequality is measured using the well-known Gini coefficient, and the data are taken from the Standardized World Income Inequality Database (Solt 2009). When measuring market inequality, the Gini coefficient for income is calculated before government taxes are subtracted from the income of each household and before potential government transfers are added to each household's income. Market inequality thus measures the level of inequality before government redistribution impacts the overall income distribution. This is different from the net inequality measure, where the Gini coefficient is measured using each household's final income after government taxes and transfers. Using market inequality rather than net inequality enables the measurement of the effect of market-based pressure for redistribution in line with the theoretical argument rather than observing potential changes in redistribution, which could be an issue with using the net inequality measure. Finally, government debt is measured in terms of the gross government debt taken from the International Monetary Fund's (IMF's) World Economic Outlook Database.

${ }^{6}$ For more information about the Economic Freedom Index in general, see Hall and Lawson (2014). 


\section{Control variables}

To control for the potential confounders of government debt, inequality and potentially also government ideology, I employ a number of economic controls. The first control is the log of gross domestic product (GDP) per capita to control for level of economic development, which is potentially endogenous to labour market regulation (Botero et al. 2004, 1366). The second control variable is growth of GDP, which could potentially affect both government debt and inequality and be endogenous to labour market regulation. Both GDP per capita and GDP growth are from the World Bank Database. The final control is the unemployment rate, which is also potentially endogenous to labour market regulation. The relationship between labour regulation and unemployment and whether stricter labour market regulation increases structural unemployment remain huge topics in the labour and comparative economics literature (Siebert 1997; Botero et al. 2004; Freeman 2009). Furthermore, for the purpose of this article, it would be reasonable to expect that unemployment levels would affect a government's propensity to increase or decrease labour market regulation. While high unemployment could induce a government to introduce labour market reforms in order to try to lower structural unemployment, relaxing employment protection in the face of high unemployment could be deemed politically unpopular by the government. The unemployment rate variable is taken from the IMF World Economic Outlook Database.

As a final political control, I use the distance between political veto actors to control for the potential policy-stability-inducing effect of disagreement between several decisionmakers. ${ }^{7}$ Several studies have found veto actor dynamics to matter for labour market reforms (Becher 2010; Avdagic 2013) and other types of economic deregulation (Smith and Urpelainen 2016). It might thus be argued that the composition of government, both regarding the number and ideology of potential coalition parties, could labour market regulation levels. I follow Avdagic (2013, 440) and use the $\operatorname{checks}^{8}$ variable from the Database of Political Institutions (Beck et al. 2001) as a proxy for the number of and ideological distance between government veto actors. As a final control, I add a dummy for whether the country is currently under an IMF programme. IMF programmes frequently come with reform conditions, ${ }^{9}$ which often concern labour market deregulation. Furthermore, the occurrence of an IMF programme is probably endogenous to the level of government debt. ${ }^{10}$ Descriptive statistics for all of the variables can be seen in Table 1.

\section{Estimation}

To estimate the effect of left-wing government control contingency on inequality and government debt, I conduct a series of fixed-effect ordinary least squares regressions with the labour market regulation index as the dependent variable. Fixed effects estimations allow me to analyse deviations from the country average

\footnotetext{
${ }^{7}$ For a comprehensive veto actor framework, see the classical work of Tsebelis (2002).

${ }^{8}$ The variable measures both the number and ideological differences between parties within the ruling government coalition.

${ }^{9}$ For a recent article on the role of the IMF in economic reforms, which also concerns partisanship, see Beazer and Woo (2015).

${ }^{10}$ The experiences of Ireland, Portugal and Greece during the European sovereign debt crisis are notable examples of this relationship.
} 
Table 1. Descriptive statistics

\begin{tabular}{lccccc}
\hline Variables & Mean & SD & Minimum & Maximum & Observations \\
\hline Labour market regulation & 3.92 & 1.56 & 0.72 & 7.19 & 433 \\
Left-wing government & 0.37 & 0.48 & 0 & 1 & 433 \\
Market inequality (Gini) & 46.44 & 4.24 & 32.44 & 56.6 & 433 \\
Government debt & 57.84 & 34.36 & 6.07 & 216 & 433 \\
Log of GDP per capita & 10.21 & 0.60 & 8.64 & 11.36 & 433 \\
GDP growth & 2.29 & 2.90 & -9 & 24.8 & 433 \\
Unemployment & 7.43 & 4 & 2 & 9 & 433 \\
Veto actor distance & 4.15 & 1.15 & 2 & 1 & 433 \\
Under IMF programme & 0.07 & 0.26 & 0 & 433 \\
\hline
\end{tabular}

Note: GDP = gross domestic product; IMF = International Monetary Fund.

and thus within-country variation in labour market regulation. They also enable me to hold the historical legacy ${ }^{11}$ and deeper cultural aspects (Alesina et al. 2015) of the different countries constant, which might also affect the level of labour market regulation. In order to address issues of autocorrelation, standard errors are clustered at the country level. The regression equation can be seen in Equation 1:

$$
\text { Regulation }_{i t}=\beta_{1}\left(\text { Leftwing }_{i t} \text { Inequality }_{i t} \text { Debt }_{i t}\right)+\beta_{2} C_{i t}+\beta_{3} V_{i t}+\varphi_{i}+\gamma_{t}+\epsilon_{i t}
$$

Regulation is the level of labour market regulation in country $i$ at time $t$. The first item on the right side is the interaction between left-wing partisanship, market inequality and government gross debt. $C$ is the constituting items of the threevariable interaction, while $V$ is a vector of controls. $\varphi_{i}$ is the country-fixed effect, while $\gamma_{t}$ is the year-fixed effect, which are included to control for a potential time trend in labour market regulation in the analysed countries. $\varepsilon$ is the error term.

When estimating the above regression, all of the explanatory variables are measured in the same year as the dependent variable. However, concerns might be raised about the timing of changes in the explanatory variables and their subsequent effect on labour market regulation. In order to address this issue in Appendix $\mathrm{A},{ }^{12}$ the core results are redone lagging all explanatory variables one year. However, these results are mostly similar to those of the main analysis.

\section{Results}

The results from the panel analyses can be seen in Table 2. In the first two columns, the potential effect of partisanship contingent on either government debt and inequality is investigated but without the three-variable interaction. The results from this initial investigation suggest that higher government debt is associated with higher levels of labour market regulation in line with other findings, which have also suggested a correlation between government debt and regulation (Berggren and Bjørnskov 2017). This effect is not magnified by left-wing government partisanship as the interaction between debt and left-wing government is actually negative and statistically insignificant. In Column 2, the left-wing

\footnotetext{
${ }^{11}$ Which some scholars might argue is an important factor in labour market regulation, especially if viewing the politics of labour market regulation through the lenses of the varieties of capitalism approach to the study of developed democracies (Thelen 2012).

${ }^{12}$ Due to data availability in the data set, the year 1985 is removed from the analysis while the year 2013 is added. The total number of observations also increases by a small margin.
} 
Table 2. Results

\begin{tabular}{|c|c|c|c|c|c|c|c|c|}
\hline & (1) & (2) & (3) & (4) & (5) & (6) & (7) & (8) \\
\hline Left-wing government & $0.2069(0.1346)$ & $-0.8706(0.9130)$ & $3.3600(1.9480)^{\star}$ & $3.3613(1.9565)^{\star}$ & $3.2666(1.9921)$ & $3.4446(2.0357)^{\star}$ & $3.3761(2.0482)$ & $3.4188(2.0154)^{\star}$ \\
\hline Market inequality & $0.0062(0.0222)$ & $-0.0061(0.0230)$ & $0.0604(0.0430)$ & $0.0639(0.0411)$ & $0.0625(0.0412)$ & $0.0588(0.0413)$ & $0.0572(0.0416)$ & $0.0508(0.0400)$ \\
\hline Government debt & $0.0070(0.0029)^{\star \star}$ & $0.0071(0.0027)^{\star \star}$ & $0.0577(0.0250)^{\star \star}$ & $0.0543(0.0233)^{\star \star}$ & $0.0537(0.0234)^{\star \star}$ & $0.0546(0.0235)^{\star \star}$ & $0.0538(0.0238)^{\star \star}$ & $0.0501(0.0219)^{\star \star}$ \\
\hline $\begin{array}{l}\text { Left-wing government } \times \\
\text { government debt }\end{array}$ & $-0.0014(0.0021)$ & $0.001+-0021$ & $-0.0783(0.0306)^{\star \star}$ & $-0.0789(0.0298)^{\star \star}$ & $-0.0776(0.0305)^{\star \star}$ & $-0.0710(0.0296)^{\star \star}$ & $-0.070(0.0298)^{\star \star}$ & $-0.0705(0.0284)^{\star \star}$ \\
\hline Left-wing government $\times$ market inequality & - & $0.0213(0.0189)$ & $-0.0661(0.0407)$ & $-0.0661(0.0404)$ & $-0.0638(0.0413)$ & $-0.0672(0.0429)$ & $-0.0657(0.0431)$ & $-0.0670(0.0424)$ \\
\hline $\begin{array}{l}\text { Market inequality } \times \\
\text { government debt }\end{array}$ & - & 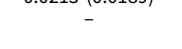 & $-0.0011(0.0005)^{\star \star}$ & $-0.0010(0.0005)^{\star}$ & $-0.0010(0.0005)^{\star}$ & $-0.0010(0.0005)^{\star \star}$ & $-0.0010(0.0005)^{\star \star}$ & $-0.0009(0.0005)^{\star}$ \\
\hline $\begin{array}{l}\text { Left-wing government } \times \text { market } \\
\text { inequality } \times \text { government debt }\end{array}$ & - & - & $0.0016(0.0006)^{\star \star}$ & $0.0016(0.0006)^{\star \star}$ & $0.0016(0.0006)^{\star \star}$ & $0.0014(0.0006)^{\star \star}$ & $0.0014(0.0006)^{\star \star}$ & $0.0014(0.0006)^{\star \star}$ \\
\hline Log of GDP per capita & - & - & - & $0.9889(1.0577)$ & $1.0155(1.0286)$ & $1.7954(0.9677)^{\star}$ & $1.7709(0.9624)^{\star}$ & $1.9138(0.9748)^{\star}$ \\
\hline GDP growth & - & - & - & - & $-0.0093(0.0181)$ & $0.0017(0.0168)$ & $0.0009(0.0165)$ & $-0.0026(0.0175)$ \\
\hline Unemployment & - & -- & - & - & - & $0.0637(0.0232)^{\star \star \star}$ & $0.0633(0.0227)^{\star \star \star}$ & $0.0642(0.0225)^{\star \star \star}$ \\
\hline Veto actor distance & - & - & - & _- & _- & - & $-0.0310(0.0509)$ & $-0.0292(0.0505)$ \\
\hline Under IMF programme & - & - & - & - & - & - & - & $-0.2557(0.1810)$ \\
\hline Country-fixed effects & Yes & Yes & Yes & Yes & Yes & Yes & Yes & $\begin{array}{l}\text { Yes } \\
\text { Yes }\end{array}$ \\
\hline Year-fixed effects & Yes & Yes & Yes & Yes & Yes & Yes & Yes & Yes \\
\hline Number of countries & 433 & 433 & 433 & 433 & 433 & 433 & 433 & 433 \\
\hline Number of observations & 33 & 33 & 33 & 33 & 33 & 33 & 33 & 33 \\
\hline Within $R^{2}$ & 0.7086 & 0.7099 & 0.7202 & 0.7244 & 0.7248 & 0.7398 & 0.7404 & 0.7439 \\
\hline
\end{tabular}

Notes: Dependent variable is labour market regulation. Standard errors clustered by country in parentheses.

$\mathrm{GDP}=$ gross domestic product; IMF = International Monetary Fund.

${ }^{\star},{ }^{\star \star},{ }^{\star \star \star}$ Significance level $0.10,0.05,0.01$, respectively. 
government dummy is interacted with market inequality and neither this interaction nor its constituting terms seem to have any statistically significant effect on labour market regulation. Left-wing governments do not seem to increase labour market regulation significantly more than other types of government when debt increases or inequality is higher. However, following the line of argument from the theoretical section, we ought to expect neither higher debt nor higher inequality to increase labour market regulation under a left-wing government independent of each other.

Turning to the test of the central argument of this article - that left-wing governments facing both high debt and higher inequality will increase labour market regulation - in Column 3, the index of labour market regulation is regressed on the interaction between left-wing government, market inequality and government debt. For the single variables in this interaction, both left-wing government and government debt have statistically significantly positive coefficients, whereas inequality in itself is not statistically significant. The interaction between left-wing government and government debt has a negative coefficient. Apparently, when not faced with the redistributive pressure from increased market inequality, left-wing governments do not react to increased levels of government debt by increasing labour market regulation, which is in line with the key theoretical argument that it is the redistributive concerns arising from changes in market income inequality which drive left-wing governments' labour market regulation policies under the constraint imposed by high government debt. The interaction between left-wing government and inequality and between inequality and government debt are also negative but only the latter is statistically significant. The latter coefficient suggests that, under non-left governments, increased market inequality actually reduces the effect of government debt on labour market regulation. Looking at the key variable of interest, the three-variable interaction between left-wing government, government debt and inequality has the expected positive sign with an effect that is statistically significant at $p>0.05$. Interpreting the coefficients of these different variables together, they seem to provide evidence in favour of the theoretical argument. In the case of a coincidence between a leftwing government, higher inequality and a high level of government debt, the level of labour market regulation increases. The theoretical argument of this article thus seems strengthened by the initial finding.

In order to test the sensitivity of the initial findings in Columns $4-8$, I add the control variables one by one. In Column 4 , the log of GDP is added to the specification, which has, in discordance with the theoretical expectation, a negative but not statistically significant effect. In the fifth column, I add the GDP growth variable, which does not seem to affect labour market regulation statistically significantly. Column 6 adds the control for the level of unemployment. Unemployment seems to have a nontrivial and statistically significant positive effect on the labour regulation index, indicating that an incumbent government would be less inclined to deregulate labour markets in the case of high unemployment and might even expand regulation in this area.

Veto actor distance is added in the seventh column as an additional political control variable. It does not seem to be a statistically significant predictor of labour market regulation. Finally, I add the dummy for IMF involvement in Column 8 . While this variable has the expected negative sign, it is not statistically significant at conventional levels. The inclusion of these various control variables does not 

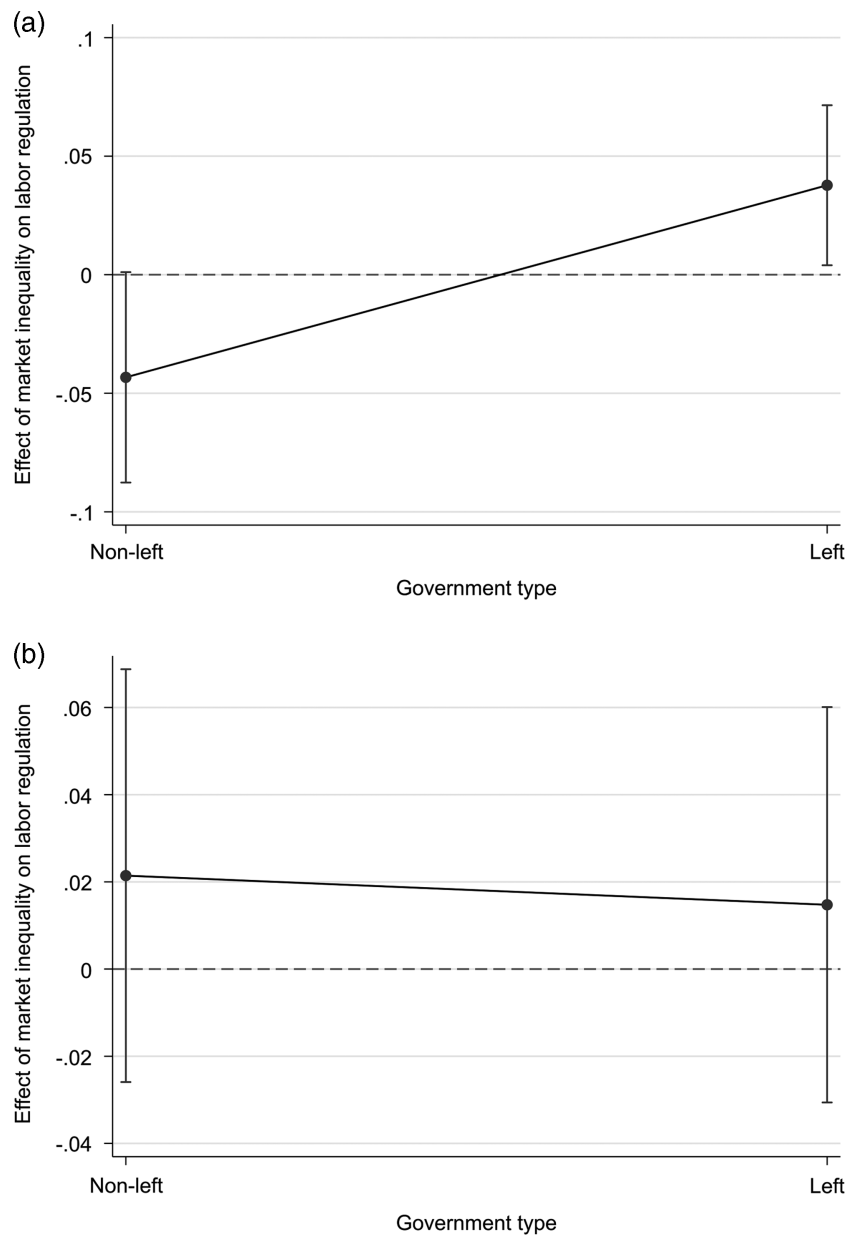

Figure 1. Effect of inequality on labour market regulation contingent on partisanship and government debt: (a) high debt level and (b) low debt level.

Note: High debt level is defined as general government debt exceeding $60 \%$ of gross domestic product. Vertical lines show $90 \%$ confidence intervals.

fundamentally change the size effect or the statistical significance of the interaction between left-wing government, inequality and government debt. The theoretical argument - that dynamics of debt, inequality and government partisanship shape labour market regulation - seems further strengthened. In all of the estimations, the sizes of the within-country $R^{2}$ are relatively high, which suggests that the model explains a large proportion of the within-country variation in labour market regulation. ${ }^{13}$

The relationship between left-wing government control, inequality and debt is visualised in Figure 1, which is based on the estimate in Column 3 of Table 2 and

\footnotetext{
${ }^{13}$ This rather large $R^{2}$ is likely driven by the year and country-fixed effects, since an empty model with these explanatory variables alone yields an $R^{2}$ of about 0.66 .
} 
shows the marginal effect of market inequality contingent on government type at different levels of government debt. As evident from Figure 1a, when government debt is high, which is defined as government debt above $60 \%$ of GDP, ${ }^{14}$ increased inequality under left-wing government partisanship causes an increase in the level of labour market regulation. Under low levels of government debt (Figure 1b), there is no statistically significant effect of inequality on labour market regulation under a left-wing government and no difference between left-wing and non-leftwing governments.

The effect size is not large but not negligible either. In the case of a government debt level of $60 \%$ of GDP (about panel average) and a left-wing incumbent government, an increase in market inequality from the lowest observation in the panel to the panel mean increases labour market regulation with one-third standard deviation. While under lower levels of government debt and under non-left-wing governments, rising market inequality has either no or no positive effect on labour market regulation. In line with the theoretical argument, when high debt levels inhibit the expansion of fiscal redistribution, left-wing governments use labour market regulation to cushion the effect of increased inequality.

\section{Robustness tests}

The above results suggest substantial evidence in favour of the argument that leftwing government control, high government debt and increased inequality might jointly increase labour market regulation. However, as always with observational studies one should be wary of an overconfident causal interpretation of the above results. Especially, left-wing government control, government debt and inequality might be endogenous to factors also related to labour market regulation but not previously controlled for. Imprecisely measured variables and potential outliers might also weaken the validity and generalisability of the results. In order to address these issues and to test the robustness of the above finding and the general validity of the theoretical argument, in this section I conduct a number of robustness tests concerning both the measurement of the key dependent variable, potentially omitted variables and the issues of outliers. ${ }^{15}$

First, I address the issue of the measurement of the dependent variable. Concerns might be raised that several of the indicators of the aggregate labour regulation index from the Economic Freedom Index are not well suited or targetable as redistributive tools. To address this concern, I redo the full analysis from Table 2 in Table 3, Column 1, but replace the full labour regulation index with an index, which is the average score of four of the six labour regulation index indicators (hiring regulation and the existence and stringency of a minimum wage, hiring and firing regulation, hours regulation and the mandated cost of worker's dismissal). These are all items that can be more directly influenced by an incumbent government and clearly hold distributional properties. Replacing the full index with this limited labour market regulation index yields the same results as the main analysis, which provides evidence in favour of the main theoretical argument about

\footnotetext{
${ }^{14}$ Which is just above the panel mean for this variable.

${ }^{15}$ Due to data availability, the number of observations and number of countries analysed decreases in some of these estimations.
} 
Table 3. Robustness tests

\begin{tabular}{|c|c|c|c|c|c|}
\hline & $\begin{array}{l}\text { Limited labour market } \\
\text { regulation index }\end{array}$ & $\begin{array}{l}\text { Control for union } \\
\text { density }\end{array}$ & $\begin{array}{l}\text { Control for public } \\
\text { revenue }\end{array}$ & $\begin{array}{c}\text { Control of postcrisis } \\
\text { years }\end{array}$ & $\begin{array}{l}\text { Excluding observations with debt } \\
\qquad>120 \% \text { of GDP }\end{array}$ \\
\hline Left-wing government & $5.0598(2.7942)^{\star}$ & $3.4846(1.6905)^{\star \star}$ & $3.2727(2.0035)$ & $3.4188(2.0154)^{*}$ & $3.4337(2.1917)$ \\
\hline Market inequality & $0.0310(0.0436)$ & $0.0442(0.0452)$ & $0.0566(0.0427)$ & $0.0508(0.0400)$ & $0.0480(0.0437)$ \\
\hline Government debt & $0.0298(0.0224)$ & $0.0462(0.0269)^{*}$ & $0.0524(0.0230)^{\star *}$ & $0.0501(0.0219)^{\star *}$ & $0.0535(0.0260)^{\star \star}$ \\
\hline Left-wing government $\times$ government debt & $-0.0935(0.0352)^{\star \star}$ & $-0.0697(0.0252)^{\star \star \star}$ & $-0.0644(0.0279)^{\star \star}$ & $-0.0705(0.0284)^{\star \star}$ & $-0.0709(0.0324)^{\star \star}$ \\
\hline Left-wing government $\times$ market inequality & $-0.1030(0.0589)^{\star}$ & $-0.0716(0.0359)^{\star}$ & $-0.0642(0.0423)$ & $-0.0670(0.0424)$ & $-0.0677(0.0466)$ \\
\hline Market inequality $\times$ government debt & $-0.0006(0.0005)$ & $-0.0008(0.0006)$ & $-0.0010(0.0005)^{\star}$ & $-0.0009(0.0005)^{\star}$ & $-0.0010(0.0006)^{\star}$ \\
\hline $\begin{array}{l}\text { Left-wing government } \times \text { market } \\
\text { inequality } \times \text { government debt }\end{array}$ & $0.0019(0.0007)^{\star \star}$ & $0.0015(0.0005)^{\star \star \star}$ & $0.0013(0.0006)^{\star \star}$ & $0.0014(0.0006)^{\star \star}$ & $0.0015(0.0007)^{\star \star}$ \\
\hline Log of GDP per capita & $3.1497(0.9193)^{\star \star \star}$ & $2.0924(0.9962)^{\star \star}$ & $1.7572(1.0404)$ & $1.9138(0.9748)^{\star}$ & $1.6806(0.9671)^{\star}$ \\
\hline GDP growth & $0.0071(0.0112)$ & $-0.0367(0.0153)^{\star \star}$ & $-0.0135(0.0143)$ & $-0.0026(0.0175)$ & $-0.0019(0.0177)$ \\
\hline Unemployment & $0.0433(0.0314)$ & $0.0543(0.0242)^{\star \star}$ & $0.0568(0.0230)^{\star \star}$ & $0.0642(0.0225)^{\star \star \star}$ & $0.0699(0.0240)^{\star \star \star}$ \\
\hline Veto actor distance & $0.0031(0.0420)$ & $0.0342(0.0511)$ & $-0.0079(0.0487)$ & $-0.0292(0.0505)$ & $-0.0274(0.0527)$ \\
\hline Under IMF programme & $0.1358(0.1896)$ & $-0.4675(0.1337)^{\star \star \star}$ & $-0.2419(0.1858)$ & $-0.2557(0.1810)$ & $-0.2298(0.1946)$ \\
\hline Union density & - & $0.0075(0.0121)$ & - & - & - \\
\hline Public revenue as percent of GDP & - & - & $-0.0006(0.01948)$ & - & - \\
\hline Post- 2008 crisis dummy & - & - & - & $-3.3806(0.9221)^{\star \star \star}$ & \\
\hline Country-fixed effects & Yes & Yes & Yes & Yes & Yes \\
\hline Year-fixed effects & Yes & Yes & Yes & Yes & Yes \\
\hline Number of countries & 33 & 28 & 33 & 33 & 33 \\
\hline Number of observations & 318 & 345 & 432 & 433 & 414 \\
\hline Within $R^{2}$ & 0.2855 & 0.7855 & 0.7492 & 0.7439 & 0.7387 \\
\hline
\end{tabular}

Notes: Dependent variable is labour market regulation except in Column 1. Standard errors clustered by country in parentheses. $\mathrm{GDP}=$ gross domestic product; IMF = International Monetary Fund

${ }^{\star},{ }^{\star \star},{ }^{\star \star \star}$ Significance level $0.10,0.05,0.01$, respectively. 
how an incumbent left-wing government might use labour regulation as a distributive tool under high debt and inequality.

I then turn to address the issues of potentially omitted variables from the main analysis. First, since previous research suggests that the influence of trade unions might significantly affect the nature and propensity of labour market reforms, ${ }^{16}$ I control for the potential organisational power of national unions by including a measure of union density from the Comparative Political Dataset (Armingeon et al. 2015) as an additional control. However, the introduction of this variable in Column 2 of Table 3 does not change the size effect and statistical significance of the key interaction between left-wing government control, inequality and government debt. Furthermore, the union density variable itself is statistically insignificant.

I then address the issue of government revenue. As noted in the theoretical section, even if a left-wing government is able to raise further public revenue (e.g. through increased taxation), in times of high debt the government will put this extra revenue towards consolidating public finances. When also faced with increased inequality, a left-wing government will use labour market regulation as an alternative redistributive tool rather than putting the extra tax revenue towards additional public transfers. However, this argument has only rested on one assumption thus far. So in order to hold the aspect of public revenue constant in Column 3 of Table 3, I add a control of public revenue as a percentage of GDP from the IMF's World Economic Outlook Database. However, adding this control does not change the size effect or statistical significance level of the key interaction variable in any significant way.

I then address the issue of the postfinancial crisis years. As noted in the introduction, the labour market reform issue became particularly salient in many European countries in the aftermath of economic and fiscal crisis following the global financial crisis of 2008, and the experiences of many countries during this period might be driving many of the previous results. In order to account for this in Column 4 of Table 3, I add a dummy that takes the value 1 in the years after 2008. While this dummy seems to have a substantial and statistically very significantly negative effect on labour market regulation, it does not seem to change the core results.

Additionally, I address the issue of potential outliers. There is massive variation among the countries included in the study with regards to their levels of government debt and especially changes in this variable over the analysed period. One concern might be that extreme values on the debt variable are driving the above results. In order to address this issue in Column 5 of Table 3, I exclude all observations with debt to GDP above 120 , which is approximately 2 standard deviations over the panel mean. However, this sample restriction does not change the size or statistical significance of the key three-variable interaction between leftwing government, inequality and government debt. Finally, to alleviate concerns that the results could be driven by very country-specific experiences, I redo the main estimation removing one country at the time from the analysis. Even with these sample restrictions, the main results stay robust. ${ }^{17}$

\footnotetext{
${ }^{16}$ See, among others, Davidson and Emmenegger (2013).

${ }^{17}$ Results are available upon request. The removal of Ireland reduces the three-variable interaction between left-wing government, inequality and government debt somewhat and increases the p-value of this
} 
Table 4. Proxy test: unemployment

(1)

Left-wing government

$3.6607(2.108)^{*}$

Market inequality

$0.0388(0.0455)$

Government debt

$0.0432(0.0250)^{*}$

Left-wing government $\times$ market inequality

$-0.0694(0.0449)$

Market inequality $\times$ government debt

$-0.0007(0.0006)$

Left-wing government $\times$ government debt

Left-wing government $\times$ market inequality $\times$ government debt

$-0.0749(0.0306)^{\star \star}$

Left-wing government $\times$ unemployment

Unemployment $\times$ government debt

Left-wing government $\times$ government debt $\times$ unemployment

$0.0015(0.0007)^{\star \star}$

$-0.0218(0.0371)$

$-0.0005(0.0006)$

$0.0002(0.0006)$

Log of GDP per capita

GDP growth

Unemployment

$2.0128(0.9463)^{\star *}$

Veto actor distance

$-0.0047(0.0181)$

$0.1025(0.0432)^{\star *}$

Under IMF programme

$-0.0233(0.0518)$

Country-fixed effects

Year-fixed effects

$-0.2335(0.1952)$

Number of countries

Yes

Yes

Number of observations

Within $R^{2}$

Notes: Dependent variable is labour market regulation. Standard errors clustered by country in parentheses. $\mathrm{GDP}=$ gross domestic product; IMF = International Monetary Fund.

${ }^{\star},{ }^{\star *}$ Significance level $0.10,0.05,0.01$, respectively.

The above results would appear to provide robust evidence in favour of the article's theoretical argument. However, an additional concern might be raised that the relevant factor for the debt-contingent effect of government partisanship on labour market regulation might not be inequality but rather unemployment, as earlier evidence from the partisan politics literature suggests that left-wing governments respond with looser fiscal policy under higher levels of unemployment than other types of government (Cusack 1999). Taking this perspective, high government debt might also inhibit further fiscal stimulus and make higher levels of labour market regulation attractive for an incumbent left-wing government. Thus, the market inequality effect might merely be a proxy for the effect of high unemployment levels. To explore whether this might be the case, in Table 4, I conduct a proxy test adding to the estimate in Table 2, Column 8 an interaction between unemployment, government debt and left-wing government to test whether the apparent debt and partisan contingent effect of inequality is just reflecting a debt and partisan contingent effect of unemployment on labour market regulation.

The results do not suggest any statistically significant effect of the interaction between left-wing partisanship, high government debt and high unemployment, since this three-variable interaction is not statistically significant despite having the expected positive sign. The three-variable interaction between left-wing government, government debt and market inequality retains its size effect and statistical significance level from Table 2. The results lend further support to the theoretical model

interaction to 0.109 , just below conventional levels of statistical significance. However, when using the limited labour market regulation index as the dependent variable the three-variable interaction is still significant at the $\mathrm{p}<0.05$ level, even when Ireland is removed. These results suggest that the theoretical argument is valid beyond Ireland. 
and the argument that the joint effect of left-wing government, government debt and market inequality can explain changes in national labour market regulation.

\section{Discussion}

The extent of labour market regulation continues to be a top policy question in many countries but the causes of variance in labour market regulation both within and between countries remain open to inquiry. This article has argued that some of the variation in labour market regulation can be explained by the role of left-wing parties in labour market regulation. Labour market regulation can reduce economic efficiency but also serves as a redistributive tool. Thus, when left-wing governments are faced with increased demand for redistribution due to higher market inequality but simultaneously faced with budget constraints due to high levels of government indebtedness, they will use increased labour regulation as redistribution.

Panel data for 33 OECD countries shows strong support for the theoretical argument. Labour market regulation is unaffected by market inequality when government debt is low but left-wing governments seem to increase labour market regulation under rising inequality if government debt is high.

The findings in this article provide a potential explanation for often-lagging labour market reforms in times of high government indebtedness, which often follow financial and other economic crises ${ }^{18}$ (Reinhart and Rogoff 2011). Given that fiscal consolidations carried out in the context of less regulated labour markets could be less economically costly (Alesina and Ardagna 2013,9), the results of this article suggest that countries facing high government debt levels, extensive labour market regulation and increases in income inequality could be caught in a vicious reform sclerosis equilibrium under left-wing governments; a situation where the left-wing government is being forced to embark on fiscal austerity due to high indebtedness but is unable to introduce economic reforms, which might cushion the effect of austerity policies since labour market policies the only way a left-wing government can redistribute to its core constituency. ${ }^{19}$

The article also contributes to the broader discussion regarding the relationship between partisan politics and inequality (Boix 2010, 493) and is of relevance for the discussion of the effect of inequality on economic growth (Banerjee and Duflo 2003). It especially provides a micro-founded explanation for the results from studies that have found an effect of inequality on economic performance contingent on government partisanship (Bjørnskov 2008).

The area of labour market regulation seems to be one policy area where different combinations of partisan orientation and economic factors can produce various different policy outcomes. Future research could explore the extent to which this also goes for other areas of government public policies. The article's main theoretical argument that tinkering with regulation levels becomes an attractive area for partisan politics when the government faces budget constraints might thus have wider implications. For an example, we might expect right-wing governments to

\footnotetext{
${ }^{18}$ Recent research by Young and Bologna (2016) also report an association between government debt crisis and increased levels of general regulation.

${ }^{19}$ Given that some recent research has suggested that left-wing parties often fare relatively poorly electorally during economic crises (Kayser and Grafström 2015), however, the equilibrium might not be prevalent.
} 
use deregulation within certain policy areas (e.g. environmental protection and labour standards) to redistribute to their core constituency, such as private businesses and entrepreneurs, when the state of government finances makes tax cuts and tax deductions to these interests less possible. ${ }^{20}$ Future research might thus investigate how partisanship and conditional economic and institutional factors impact the nature of public regulation between and within countries beyond labour market policies.

Acknowledgements. The author would like to thank Mathias Heinze Pedersen, Brett Meyer and seminar participants at Hertie School of Governance as well as the editor and three anonymous reviewers for help, suggestions and advice. All errors remain the authors own.

\section{References}

Acemoglu D and Robinson JA (2001) Inefficient Redistribution. American Political Science Review 96(3): 649-661.

Alesina A, Algan Y, Cahuc P and Giuliano P (2015) Family Values and the Regulation of Labor. Journal of the European Economic Association 13(4): 599-630.

Alesina A and Ardagna S (2013) The Design of Fiscal Consolidations. NBER Working Paper No. 18423.

Armingeon K, Isler C, Knöpfel L, Weisstanner D and Engler S (2015) Comparative Political Data Set 1960-2013. Bern: Institute of Political Science, University of Berne.

Avdagic S (2013) Partisanship, Political Constraints, and Employment Protection Reforms in an Era of Austerity. European Political Science Review 5(3): 431-455.

Banerjee AV and Duflo E (2003) Inequality and Growth: What Can the Data Say? Journal of Economic Growth 8(3): 267-299.

Beazer QH and Woo B (2015) IMF Conditionality, Government Partisanship, and the Progress of Economic Reforms. American Journal of Political Science 60(2): 304-321.

Becher M (2010) Constraining Ministerial Power: The Impact of Veto Players on Labor Market Reforms in Industrial Democracies, 1973-2000. Comparative Political Studies 43(1): 33-60.

Beck T, Clarke G, Groff A, Keefer P and Walsh P (2001) New Tools in Comparative Political Economy: The Database of Political Institutions. World Bank Economic Review 15(1): 165-176.

Berggren N and Bjørnskov C (2017) Regulation and Government Debt. Institute for Research in Economic and Fiscal Issues Working Paper.

Besley T and Burgess R (2004) Can Labor Regulation Hinder Economic Performance? Evidence from India. The Quarterly Journal of Economics 119(1): 91-134.

Bjørnskov C (2008) The Growth-Inequality Association: Government Ideology Matters. Journal of Development Economics 87(2): 300-308.

Boeri T, Conde-Ruiz JI and Galasso V (2012) The Political Economy of Flexicurity. Journal of the European Economic Association 10(4): 684-715.

Boix C (2010) Origins and Persistence of Economic Inequality. Annual Review of Political Science 16, 489-516.

Botero JC, Djankov S, La Porta R, Lopez-De-Silanes F and Shleifer A (2004) The Regulation of Labor. The Quarterly Journal of Economics 119(4): 1339-1382.

Cusack TR (1999) Partisan Politics and Fiscal Policy. Comparative Political Studies 32(4): 464-486.

Davidson JB and Emmenegger P (2013) Defending the Organisation, Not the Members: Unions and the Reform of Job Security Legislation in Western Europe. European Journal of Political Research 52, 339-363.

Dew-Becker I and Gordon RJ (2008) The Role of Labor Market Changes in the Slowdown of European Productivity Growth. NBER Working Paper No. 13840.

Di Giacchino D and Sabani L (2009) The Politics of Social Protection: Social Expenditures vs Market Regulation. International Review of Applied Economics 23(3): 387-404.

Di Giacchino D, Sabani L and Tedeschi S (2014) Preferences for Social Protection: Theory and Empirics. Economic Modelling 36, 629-644.

\footnotetext{
${ }^{20}$ I thank the article's reviewers for bringing this implication of the main theoretical argument to my attention.
} 
Djankov S, McLiesh C and Ramalho RM (2006) Regulation and Growth. Economics Letters 92(3): 395-401.

Feldmann H (2009) The Unemployment Effects of Labor Regulation Around the World. Journal of Comparative Economics 37, 76-90.

Freeman RB (2009) Labor Regulation, Unions, and Social Protection in Developing Countries: Markets Distortions or Efficient Institutions. NBER Working Paper No. 14789.

Gwartney J, Lawson R and Hall J (2015) Economic Freedom of the World: 2015 Annual Report. Vancouver: Fraser Institute.

Hall J and Lawson RA (2014) Economic Freedom of the World: An Accounting of the Literature. Contemporary Economic Policy 32(1): 1-19.

Häusermann S, Picot G and Geering D (2013) Review Article: Rethinking Party Politics and the Welfare State - Recent Advances in the Literature. British Journal of Political Science 43, 221-240.

Hibbs DA Jr (1977) Political Parties and Macroeconomic Policy. American Political Science Review 71(4): 1467-1487.

Hübscher E (2016) The Politics of Fiscal Consolidation Revisited. Journal of Public Policy 36(4): 573-601.

Iversen T and Soskice D (2006) Electoral Institutions and the Politics of Coalitions: Why Some Democracies Redistribute More than Others. American Political Science Review 100(2): 165-181.

Kayser MA and Grafström C (2015) The Austerity Vote: How the Left Loses from Asymmetric Partisan Accountability. Working Paper.

Kemmerling A and Bruttel O (2006) New Politics in German Labour Market Policy? The Implications of the Recent Hartz Reforms for the German Welfare State. West European Politics 29(1): 90-112.

Lindvall J and Rueda D (2014) The Insider-Outsider Dilemma. British Journal of Political Science 44(2): 460-475.

Meltzer AH and Richard SF (1981) A Rational Theory of the Size of Government. Journal of Political Economy 89, 914-927.

Meyer B (2016) Learning to Love the Government: Trade Unions and Late Adoption of the Minimum Wage. World Politics 68(3): 538-575.

Nickell S and Layard R (1999) Labor Market Institutions and Economic Performance. In Ashenfelter OC and Card D (eds.), Handbook of Labor Economics Volume 3C. Amsterdam: Elsevier North Holland: 3029-3084.

Pontusson J and Rueda D (2010) The Politics of Inequality: Voter Mobilization and Left Parties in Advanced Industrial States. Comparative Political Studies 43, 675-705.

Potrafke N (2010) Labor Market Deregulation and Globalization: Empirical Evidence from OECD Countries. Review of World Economics 146(3): 545-571.

Reinhart CM and Rogoff KS (2011) From Financial Crash to Debt Crisis. American Economic Review 101, 1676-1706.

Schneider F (2010) The Influence of Public Institutions on the Shadow Economy: An Empirical Investigation for OECD Countries. Review of Law and Economics 6(3): 441-468.

Siebert H (1997) Labor Market Rigidities: At the Root of Unemployment in Europe. The Journal of Economic Perspectives 11(3): 37-54.

Smith MG and Urpelainen J (2016) Windows of Opportunity: Legislative Fragmentation Conditions the Effect of Partisanship on Product Market Deregulation. Journal of Public Policy 36(1): 51-86.

Solt F (2009) Standardizing the World Income Inequality Database. Social Science Quarterly 90(2): 231-242.

Tavares J (2004) Does Right or Left Matter? Cabinets, Credibility and Fiscal Adjustments. Journal of Public Economics 88, 2447-2468.

Tavits M and Potter JD (2015) The Effect of Inequality and Social Identity on Party Strategies. American Journal of Political Science 59(3): 744-758.

Thelen K (2012) Varieties of Capitalism: Trajectories of Liberalization and the New Politics of Social Solidarity. Annual Review of Political Science 15, 137-159.

Tsebelis G (2002) Veto Players: How Political Institutions Works. Princeton, NJ: Princeton University Press.

Young AT and Bologna J (2016) Crisis and Government: Some Empirical Evidence. Contemporary Economic Policy 34(2): 234-249.

Cite this article: Aaskoven L. 2019. Redistributing under fiscal constraint: partisanship, debt, inequality and labour market regulation. Journal of Public Policy 39: 423-441, doi:10.1017/S0143814X18000193 


\section{Appendix A}

Table A1. Core results with lagged explanatory variables

\begin{tabular}{|c|c|c|c|c|c|c|c|c|}
\hline & (1) & (2) & (3) & (4) & (5) & (6) & (7) & (8) \\
\hline Left-wing government & $0.3346(0.1570)^{\star \star}$ & $-0.6078(0.9013)$ & $4.4033(2.0823)^{\star \star}$ & $4.4142(2.1122)^{\star \star}$ & $4.1868(2.2151)^{\star}$ & $4.3441(2.2727)^{\star}$ & $4.3402(2.2828)^{\star}$ & $4.3061(2.2828)^{\star}$ \\
\hline Market inequality & $-0.0050(0.0191)$ & $-0.0151(0.0202)$ & $0.0773(0.0417)^{\star}$ & $0.0785(0.0407)^{\star}$ & $0.0752(0.0399)^{\star}$ & $0.0728(0.0415)^{\star}$ & $0.0728(0.0415)^{\star}$ & $0.0627(0.0403)$ \\
\hline Government debt & $0.0071(0.0031)^{\star \star}$ & $0.0069(0.0028)^{\star \star}$ & $0.0774(0.0266)^{\star \star \star}$ & $0.0754(0.0256)^{\star \star \star}$ & $0.0741(0.0253)^{\star \star \star}$ & $0.0750(0.02650)^{\star \star \star}$ & $0.0749(0.0265)^{\star \star \star}$ & $0.0698(0.0236)^{\star \star \star}$ \\
\hline Left-wing government $\times$ government debt & $-0.0019(0.0024)$ & - & $-0.0925(0.0305)^{\star \star \star}$ & $-0.0933(0.0307)^{\star \star \star}$ & $-0.0900(0.0318)^{\star \star \star}$ & $-0.0878(0.0319)^{\star \star \star}$ & $-0.0877(0.0322)^{\star \star \star}$ & $-0.0872(0.0311)^{\star \star \star}$ \\
\hline Left-wing government $\times$ market inequality & - & $0.0178(0.0194)$ & $-0.0852(0.0453)^{\star}$ & $-0.0853(0.0455)^{\star}$ & $-0.0803(0.0477)$ & $-0.0832(0.0492)^{\star}$ & $-0.0832(0.0493)$ & $-0.0828(0.0493)$ \\
\hline Market inequality $\times$ government debt & - & - & $-0.0015(0.0005)^{\star \star}$ & $-0.0014(0.0005)^{\star \star}$ & $-0.0014(0.0005)^{\star \star}$ & $-0.0015(0.0006)^{\star \star \star}$ & $-0.0015(0.0006)^{\star \star}$ & $-0.0013(0.0005)^{\star \star}$ \\
\hline $\begin{array}{l}\text { Left-wing government } \times \text { market } \\
\text { inequality } \times \text { government debt }\end{array}$ & - & - & $0.0019(0.0006)^{\star \star \star}$ & $0.0019(0.0006)^{\star \star \star}$ & $0.0018(0.0007)^{\star \star \star \star}$ & $0.0018(0.0007)^{\star \star \star}$ & $0.0018(0.0007)^{\star \star}$ & $0.0018(0.0007)^{\star \star}$ \\
\hline Log of GDP per capita & - & - & - & $0.6160(0.9790)$ & $0.6593(0.9518)$ & $1.2272(0.9529)$ & $1.2258(0.9546)$ & $1.4105(0.9636)$ \\
\hline GDP growth & - & - & - & - & $-0.0099(0.0166)$ & $-0.0033(0.0167)$ & $-0.0035(0.0173)$ & $-0.0076(0.0169)$ \\
\hline Unemployment & - & - & - & - & - & $0.0424(0.0244)^{\star}$ & $0.0423(0.0245)^{\star}$ & $0.0439(0.0253)^{\star}$ \\
\hline Veto actor distance & - & - & - & - & - & - & $-0.0051(0.0356)$ & $-0.0005(0.0348)$ \\
\hline Under IMF programme & - & - & - & - & - & - & - & $-0.3218(0.1650)^{\star}$ \\
\hline Country-fixed effects & Yes & Yes & Yes & Yes & Yes & Yes & Yes & Yes \\
\hline Year-fixed effects & Yes & Yes & Yes & Yes & Yes & Yes & Yes & Yes \\
\hline Number of countries & 450 & 450 & 450 & 450 & 450 & 450 & 450 & 450 \\
\hline Number of observations & 33 & 33 & 33 & 33 & 33 & 33 & 33 & 33 \\
\hline Within $R^{2}$ & 0.7054 & 0.7057 & 0.7224 & 0.724 & 0.7245 & 0.7311 & 0.7311 & 0.7372 \\
\hline
\end{tabular}

Notes: Dependent variable is labour market regulation. Standard errors clustered by country in parentheses.

$\mathrm{GDP}=$ gross domestic product; IMF = International Monetary Fund.

${ }^{*},{ }^{\star \star},{ }^{* \star \star}$ Significance level $0.10,0.05,0.01$, respectively. 